\title{
A Study of Female Board Directors Correlation With the Board Decision - Making Efficiency-- Based on Automobile Manufacturing Industry Listed Companies' Empirical Evidence
}

\author{
Dandan Dong ${ }^{1, *}$ and Aimin $\mathrm{Li}^{2}$ \\ ${ }^{1}$ Engineering Management Department, Zhengzhou University, Zhengzhou, China \\ ${ }^{2}$ Engineering Management Department, Zhengzhou University, Zhengzhou, China \\ Corresponding author: Dong Dan-dan 1392525437@qq.com
}

\begin{abstract}
This paper studies the correlation between the female board directors and Board decision-making behavior, from a gender perspective to our board, using multivariate regression method,choosing the number of women directors, the proportion of female directors and women directors average educational background as a measure of the Board female directors feature variable index, and the frequency of board meetings as a measure of the Board decision-making efficiency, and China's automobile manufacturing industry listed companiesdata between 2006 and 2014 as research samples. This paper find that the number of women directors, the proportion of female directors and women directors average educational background are significantly negatively correlated with the Board decision-making efficiency.

Keywords. Female directors, board of directors, board decision - making efficiency.
\end{abstract}

\section{Introduction}

The board of directors plays a dominant role in the corporate governance. The efficiency of the corporate governance is closely related to the function of the board. while the rationality of the board structure directly determines the effective functioning of the board of directors. As the economic is developing dramatically, more and more women participate in the work, and gradually enter into the company's management positions.

At present, although domestic academia has gradually begun to study the relevance between board gender diversity and corporate governance, the literatures which directly studied the relation between female directors and board decision - making efficiency in Chinese companies are very little. Therefore, this paper carries on the empirical analysis to the relationship between the female director and the board decision-making efficiency in automobile manufacturing industry listed companies .

\section{Literature review}

Some foreign or chinese scholars have started to study the relationship between board and enterprise performance from the gender perspective, but the conclusions of the studies are not very consistent, a large part of the studies found that female director has a positive impact on board behavior, and others showed that the impact is negative or uncertain . 
Triana, Maria del Carmen [1]et al. (2014) showed that at least three women was the first condition for promoting gender equality. Schwab, Andreas and Werbel, James D. et al. [2](2016) studied the relationship between managing gender diversity and firm performance ,they found that the introduction of female managers has a positive impact on firm performance. In addition, Boulouta, Ioanna [3](2013) explored the link between gender diversification and business performance follows the inverted $U$ shape based on panel data collected from 151 German public companies from the period 2000-2005, based on the critical mass theory. While,Abdullah, Shamsul N., Ismail, Ku Nor Izah Ku and Nachum, Lilac [4] (2016) found that gender diversification sometimes positively affects board behavior and creates value for some firms, However, it sometimes has negative impact on board of directors conduct, and take a loss to the company.

Yan Yonghai [5]inspected the relationship between board of directors gender diversification and financial performance of the board, and found that gender diversity and corporate financial performance have a positive correlation. While, Cheng Rui et al. [6]studied the risk aversion and board assurances of female director, and found the higher the proportion of female directors and directors in the company, the more conservative the decisions made by the board of directors. .But, ChangMengmeng [7] found the gender of that CEO orchairman don not have a significant impact on company's financing decisions .

\section{Research designs}

\subsection{Study samples}

According to the classification standard of the industry in 2012, this paper selects listed companies in Shanghai and Shenzhen A-share automobile manufacturing industry from 2006 to 2014 as research samples to study the correlation between female directors and board decision-making efficiency.

In this paper, the original data were screened according to the following principles: (1) remove ST companies; (2) remove companies which have incomplete data. After the above-mentioned treatment, we get the sample observations of 42 listed companies. Data from Guotai'an database, the data are calculated using Minitab for analysis.

\subsection{The selection and definition of variables}

(1) Interpreted variable. In this paper, the Board of Directors annual meeting frequency (BMF) is choosed to measure the efficiency of board decisions, the higher the frequency of the annual meeting of the Board, indicating that the lower the efficiency of board decision-making, the contrary is higher.

(2) Explanatory variables. this paper mainly used these three variables, the number of female directors (FD), female directors Percentage (FADPER), the average level of education of female directors (EDU).As according to related researches, this paper divides the academic degree of female directors into five categories, including secondary, tertiary, undergraduate, master and doctor, the corresponding scores are 1 point, 2 points, 3 points, 4 points, and 5 points, the total score of all the female directors in the sample companies is added together and then is divided by the average number of female directors to get average value which is the average level of education of the company's female directors.

(3) Control variables. In order to maximize avoiding other factors effect on the research results, the size of board of directors (BS), the proportion of independent directors (IDR), size of company (SIZE),equity checks and balances (SHS) and asset-liability ratio (DAR) were choosed to control the company's size and capital structure drawing on existing researches in this paper.

Explained variables, explanatory variables and control variables are defined and described in Table 1. 
Table 1. Variable definitions and descriptions.

\begin{tabular}{|l|l|l|}
\hline Project & $\begin{array}{l}\text { Variables } \\
\text { Name }\end{array}$ & Definition and Metering \\
\hline $\begin{array}{l}\text { Explained } \\
\text { variable }\end{array}$ & BMF & Number of meetings held by the Board each year \\
\hline \multirow{5}{*}{$\begin{array}{l}\text { Explanatory } \\
\text { variables }\end{array}$} & FD & $\begin{array}{l}\text { The number of women in the board of directors, and if } \\
\text { companies have no female director,it will be zero }\end{array}$ \\
\cline { 2 - 3 } & EDU & $\begin{array}{l}\text { The ratio of the number of female directors to the size of the } \\
\text { board of directors }\end{array}$ \\
\hline \multirow{5}{*}{$\begin{array}{l}\text { Control } \\
\text { variables }\end{array}$} & $\begin{array}{l}\text { Female director's grade scores are added together to arrive at the } \\
\text { sum divided by the number of female directors and get the } \\
\text { average value }\end{array}$ \\
\cline { 2 - 4 } & IDR & Total number of directors \\
\cline { 2 - 3 } & SIZE & The ratio of the total number of directors to the board size \\
\cline { 2 - 3 } & SHS & $\begin{array}{l}\text { The ratio of the number of shares held by the top ton } \\
\text { shareholders to the total share capital at the end of the year }\end{array}$ \\
\hline & The ratio of total liabilities to total assets \\
\hline
\end{tabular}

\subsection{Model design}

From the above theoretical analysis, this paper uses multiple linear regression model as follows:

$$
\begin{aligned}
& B M F=\beta_{0}+\beta_{1} F D+\beta_{2} B S+\beta_{3} I D R+\beta_{4} S I Z E+\beta_{5} S H S+\beta_{6} D A R+\varepsilon \\
& B M F=\beta_{0}+\beta_{1} F D I+\beta_{2} B S+\beta_{3} I D R+\beta_{4} S I Z E+\beta_{5} S H S+\beta_{6} D A R+\varepsilon \\
& B M F=\beta_{0}+\beta_{1} E D U+\beta_{2} B S+\beta_{3} I D R+\beta_{4} S I Z E+\beta_{5} S H S+\beta_{6} D A R+\varepsilon
\end{aligned}
$$

Where $\beta_{0}$ is the constant term of the model, $\beta(i=1,2, \ldots 6)$ is the coefficient of the explanatory variable and the control variable, and $\varepsilon$ is the random error term.

\section{Empirical analysis}

\subsection{Descriptive statistical analysis of variables}

Table 2. Descriptive statistics of variables.

\begin{tabular}{|c|c|c|c|c|c|c|c|}
\hline & $\begin{array}{c}\text { Number } \\
\text { of valid } \\
\text { data }\end{array}$ & $\begin{array}{c}\text { Number of } \\
\text { missing } \\
\text { data }\end{array}$ & Minimum & Maximum & Mean & $\begin{array}{c}\text { Standard } \\
\text { deviation }\end{array}$ & variance \\
\hline FD & 378 & 0 & 0.000 & 4.000 & 0.794 & 0.958 & 0.918 \\
\hline FADPER & 378 & 0 & 0.000 & 0.444 & 0.079 & 0.096 & 0.009 \\
\hline EDU & 378 & 0 & 0.000 & 5.000 & 0.601 & 1.351 & 1.824 \\
\hline BS & 378 & 0 & 5.000 & 22.000 & 10.048 & 2.463 & 6.067 \\
\hline IDR & 378 & 0 & 0.200 & 0.600 & 0.356 & 0.054 & 0.003 \\
\hline
\end{tabular}




\begin{tabular}{|c|c|c|c|c|c|c|c|}
\hline SIZE & 378 & 0 & 18.939 & 26.751 & 22.097 & 1.339 & 1.792 \\
\hline SHS & 378 & 0 & 0.189 & 0.880 & 0.545 & 0.153 & 0.024 \\
\hline DAR & 378 & 0 & 0.000 & 1.226 & 0.572 & 0.161 & 0.026 \\
\hline BMF & 378 & 0 & 3.000 & 36.000 & 8.484 & 3.442 & 11.847 \\
\hline
\end{tabular}

From the descriptive statistics of the variables in Table 2, it can be found that the average frequency of annual board meetings in sample enterprises is 8.484 , The average number of female directors is 0.794 , the minimum proportion of female directors is 0 , the average is $7.9 \%$, the overall proportion of female directors is very low. The average educational background of female directors is 0.000 , the highest is 5.000 . While the average is 0.601 , it has not reached the level of college, meaning that the average overall educational background of female directors in Chinese automobile manufacturing industry is low and not dominant

Table 3. Annual distribution of female directors.

\begin{tabular}{|c|c|c|c|c|c|c|c|c|c|c|c|c|}
\hline FD & \multicolumn{2}{|c|}{2006} & \multicolumn{3}{|c|}{2007} & \multicolumn{2}{|c|}{2008} & \multicolumn{3}{|c|}{2009} & \multicolumn{2}{|c|}{2010} \\
\hline $\begin{array}{c}\text { Numb } \\
\text { er }\end{array}$ & $\begin{array}{c}\text { Freque } \\
\text { cy }\end{array}$ & $\begin{array}{c}\text { Percen } \\
\text { tage }\end{array}$ & $\begin{array}{r}\text { Frec } \\
n \mathrm{nc}\end{array}$ & & $\begin{array}{c}\text { Percen } \\
\text { tage }\end{array}$ & $\begin{array}{c}\text { Freque } \\
\text { ncy }\end{array}$ & $\begin{array}{c}\text { Percen } \\
\text { tage }\end{array}$ & $\begin{array}{c}\text { Freque } \\
\text { ncy }\end{array}$ & $\begin{array}{r}\mathrm{Pel} \\
\text { ta }\end{array}$ & & $\begin{array}{c}\text { Freque } \\
\text { ncy }\end{array}$ & $\begin{array}{c}\text { Percen } \\
\text { tage }\end{array}$ \\
\hline 0 & 18 & 42.86 & 22 & & 52.38 & 20 & 47.62 & 21 & 50 & & 22 & 52.38 \\
\hline 1 & 18 & 42.86 & 12 & & 28.57 & 12 & 28.57 & 13 & & & 13 & 30.95 \\
\hline 2 & 5 & 11.90 & 7 & & 16.67 & 9 & 21.43 & 6 & & & 4 & 9.52 \\
\hline 3 & 1 & 2.38 & 1 & & 2.38 & 1 & 2.38 & 0 & 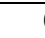 & & 3 & 7.14 \\
\hline 4 & 0 & 0 & 0 & & 0 & 0 & 0 & 2 & & & 0 & 0 \\
\hline Total & 42 & 100 & 42 & & 100 & 42 & 100 & 42 & & & 42 & 100 \\
\hline FD & \multicolumn{3}{|c|}{2011} & \multicolumn{3}{|c|}{2012} & \multicolumn{3}{|c|}{2013} & \multicolumn{3}{|c|}{2014} \\
\hline $\begin{array}{c}\text { Numb } \\
\text { er }\end{array}$ & $\begin{array}{c}\text { Frequenc } \\
\mathrm{y}\end{array}$ & \multicolumn{2}{|c|}{$\begin{array}{l}\text { Percenta } \\
\text { ge }\end{array}$} & \multicolumn{2}{|c|}{$\begin{array}{c}\text { Frequenc } \\
y\end{array}$} & $\begin{array}{l}\text { Percenta } \\
\text { ge }\end{array}$ & $\begin{array}{c}\text { Frequenc } \\
\mathrm{y}\end{array}$ & \multicolumn{2}{|c|}{$\begin{array}{l}\text { Percenta } \\
\text { ge }\end{array}$} & \multicolumn{2}{|c|}{$\begin{array}{c}\text { Frequenc } \\
\mathrm{y}\end{array}$} & $\begin{array}{l}\text { Percenta } \\
\text { ge }\end{array}$ \\
\hline 0 & 23 & \multicolumn{2}{|c|}{54.76} & & 21 & 50.00 & 21 & \multicolumn{2}{|c|}{50.00} & & 19 & 45.24 \\
\hline 1 & 11 & \multicolumn{2}{|c|}{26.19} & & 10 & 23.81 & 9 & \multicolumn{2}{|c|}{21.43} & & 11 & 26.19 \\
\hline 2 & 4 & \multicolumn{2}{|c|}{9.52} & & 6 & 14.29 & 10 & \multicolumn{2}{|c|}{23.81} & & 10 & 23.81 \\
\hline 3 & 3 & \multicolumn{2}{|c|}{7.14} & & 3 & 7.14 & 1 & \multicolumn{2}{|c|}{2.38} & & 2 & 4.76 \\
\hline 4 & 1 & \multicolumn{2}{|c|}{2.38} & & 2 & 4.76 & 1 & \multicolumn{2}{|c|}{2.38} & & 0 & 0 \\
\hline Total & 42 & \multicolumn{2}{|c|}{100} & & 42 & 100 & 42 & \multicolumn{2}{|c|}{100} & & 42 & 100 \\
\hline
\end{tabular}

Table 4. Correlation statistical analysis.

\begin{tabular}{|c|c|c|c|c|c|c|c|c|c|}
\hline & FD & FDI & EDU & BS & IDR & SIZE & SHS & DAR & BMF \\
\hline FD & 1.000 & & & & & & & & \\
& ----- & & & & & & & & \\
\hline FDI & $0.960^{* * *}$ & 1.000 & & & & & & & \\
& $(0.000)$ & ----- & & & & & & & \\
\hline EDU & $0.366^{* * *}$ & $0.411^{* *}($ & 1.000 & & & & & & \\
& $(0.000)$ & $0.000)$ & ----- & & & & & \\
\hline BS & $0.167^{* * *}$ & -0.021 & $-0.089^{*}$ & 1.000 & & & & & \\
& $(0.001)$ & $(0.685)$ & $(0.084)$ & ----- & & & & \\
\hline IDR & -0.052 & -0.033 & 0.013 & $-0.174^{* *}$ & 1.000 & & & \\
& $(0.318)$ & $(0.526)$ & $(0.800)$ & $*(0.001)$ & ----- & & & \\
\hline SIZE & $-0.199^{* *}$ & $-0.234^{* *}$ & $-0.071(0$. & $0.325^{* *}$ & $-0.226^{* *}$ & 1.000 & & & \\
& $*$ & $*(0.000)$ & $167)$ & $*$ & $*(0.000)$ & ----- & & & \\
& $(0.000)$ & & & $(0.000)$ & & & & \\
\hline SHS & $-0.279^{* *}$ & $-0.298^{* *}$ & 0.079 & $0.031(0$. & $-0.088^{*}($ & $0.348^{* * *}$ & 1.000 & & \\
& $*(0.000)$ & $(0.000)$ & $(0.127)$ & $552)$ & $0.088)$ & $(0.000)$ & ----- & & \\
\hline DAR & -0.031 & -0.028 & -0.065 & $0.099^{*}(0$ & -0.010 & -0.047 & $-0.154^{* *}$ & 1.000 & \\
& $(0.554)$ & $(0.594)$ & $(0.209)$ & $.055)$ & $(0.850)$ & $(0.364)$ & $(0.003)$ & ----- & \\
\hline
\end{tabular}




\begin{tabular}{|c|c|c|c|c|c|c|c|c|c|}
\hline BMF & $0.157^{* * *}$ & 0.082 & & $0.280^{* *}$ & -0.025 & $0.113 * *$ & 0.036 & 0.010 & 1.000 \\
$(0.002)$ & $(0.114)$ & $\begin{array}{c}0.059(0 . \\
250)\end{array}$ & $*(0.000)$ & $(0.633)$ & $(0.028)$ & $(0.487)$ & $(0.840)$ & ----- \\
\hline
\end{tabular}

Notes. $* * *$ indicates a significant correlation at 0.01 level (both sides), $* *$ indicates significant correlation at 0.05 level (both sides), and $*$ indicates significant correlation at 0.1 level (both sides)

Table 5. Summary of models.

\begin{tabular}{|c|c|c|c|c|c|c|c|}
\hline Model & $\mathbf{R}$ & $\begin{array}{c}\text { R } \\
\text { square }\end{array}$ & $\begin{array}{c}\text { Adjust } \\
\text { the R } \\
\text { square }\end{array}$ & $\begin{array}{c}\text { Standard } \\
\text { estimation } \\
\text { error }\end{array}$ & \multicolumn{3}{|c|}{ Change the statistics } \\
\cline { 6 - 8 } & & & & $\begin{array}{c}\text { R-side } \\
\text { change }\end{array}$ & F change & Sig.change \\
\hline 1 & 0.313 & 0.098 & 0.084 & 3.564 & 0.098 & 6.714 & 0.000 \\
\hline 2 & 0.303 & 0.092 & 0.077 & 3.584 & 0.092 & 6.238 & 0.000 \\
\hline 3 & 0.293 & 0.086 & 0.071 & 3.476 & 0.086 & 5.816 & 0.000 \\
\hline
\end{tabular}

Table 6.Regression analysis.

\begin{tabular}{|c|c|c|c|c|c|c|}
\hline \multirow{2}{*}{ Variable } & \multicolumn{2}{|c|}{ Model 1 } & \multicolumn{2}{c|}{ Model 2 } & \multicolumn{2}{c|}{ Model 3 } \\
\cline { 2 - 7 } & $\mathrm{B}$ & Sig. & $\mathrm{B}$ & Sig. & $\mathrm{B}$ & Sig. \\
\hline Constant & 0.027 & 0.994 & 0.453 & 0.900 & 2.071 & 0.552 \\
\hline FD & 0.534 & 0.006 & & & & \\
\hline FDI & & & 4.268 & 0.025 & & 0.211 \\
\hline EDU & & & & & 0.393 & 0.000 \\
\hline BS & 0.335 & 0.000 & 0.379 & 0.000 & 2.043 & 0.533 \\
\hline ID & 2.764 & 0.398 & 2.686 & 0.413 & 0.084 & 0.566 \\
\hline SIZE & 0.149 & 0.316 & 0.121 & 0.415 & 0.076 & 0.950 \\
\hline SHS & 1.025 & 1.406 & 0.930 & 0.454 & -0.495 & 0.656 \\
\hline DAR & -0.289 & 0.793 & -0.412 & 0.708 & & \\
\hline
\end{tabular}

As can be seen from Table 3, there are about $50 \%$ of listed companies have no female directors every year. In addition, during this period also find most of the listed companies have one female director, the proportion is $23 \%$ or more.From 2013 to 2014, the proportion of listed companies with twofemale directors is on the rise. From 2009 onward, with four female directorsof listed companies appear. However, its proportion is less than $10 \%$.

\subsection{Correlation analysis of variables}

From the data in Table 4, it can be found that the number of female directors is significantly positively related to the frequency of board meeting, but the proportion of female directors is not significant with it. And the correlation coefficients of the three explanatory variablesare mostly less than 0.5 , so there is little likelihood of multiple collinearities between them, willnot affect the multiple linear regression band.

\subsection{Regression analysis}

From the model summary and regression coefficients in Table 5, it can be found the R-level coefficients are 0.098 , 0.092 and 0.086, all the significant results are 0.000. Since the R-level coefficients are positive, it can be obtained there is no linear relationship between the explanatory variables and interpreted variables, and the significance level is 0.000 , which was far less than 0.001, indicating a high level of significance. All of the three models had good goodness of fit, proving the three explanatory variables could explain the interpreted variables well, and the coefficient of predictive variables reachsignificance level.

As can be seen from Table 6, there is a positive correlation between the number of female directors, the proportion of female directors, the average educational background of female directors and frequency of board meetings, which are 
significant at the levels of $0.01,0.05$ and 0.1 respectively. This shows that female directors are negatively correlated with board decision making efficiency.

\section{Robustness test}

In order to test the rationality and robustness of the model, the stability test is carried out.

(A)In the descriptive statistical analysis we find that there was a big gap in the companies asset-liability ratio, so this article removes the companies whose asset liability rate is more than $100 \%$, then take regression analysis, the result is in agreement with the above analysis.

(B)In order to ensure that this screening does not affect the results, this article joins this part of the companies in regression analysis, the result is consistent with the above analysis.

(C)As with combination of the two cases, removing the companies whose asset liability rate was more than $100 \%$ and adding the companies by ST, then take regression analysis, the result is consistent with the above analysis.

\section{Conclusions}

This paper studies the influence of female directors on board decision - making efficiency in 42 listed companies in Shanghai and Shenzhen A-share automobile manufacturing industry from 2006 to 2014. The results shows that the number of female directors, the proportion of female directors and the average educational background of female directors are negatively related to board decision - making efficiency. Although, according to the individual cognitive limitations theory, the participation of female directors can help the company to make a comprehensive scientific decision-making. This paper gets the conclusion that the female director was negatively correlated with board decision making efficiency. First of all, this may be related to the samples selected in this paper. Only took 42 companies in the listed companies in the automobile manufacturing industry as the sample, the scope of the sample is not big enough .Second, the study results would be affected by the survey interval, the selected study interval is not long enough.Finally, in practice, the board decision - making efficiency may also be affected by other factors,for example, the higher the average educational background of female directors, the more likely it will be the phenomenon of contention, which will bring some impact to the research result.

\section{References}

1. Triana, Mariadel Carmen, Miller, Toyah L., Trzebiatowski, Tiffany M..TheDouble-EdgedNature of Board Gender Diversity: Diversity, Firm Performance, and the Powerof Women Directors as Predictors of Strategic Change.J.Organization Science,25,2(2014).

2. Schwab, Andreas,Werbel, James D., Hofmann, Heike.Managerial Gender Diversity and Firm Performance: An Integration of Different Theoretical Perspectives.J.Group \& Organization Management,41,1(2016).

3. Boulouta, Ioanna.Hidden Connections: The Link Between Board Gender Diversity and Corporate Social Performance.J.Journal Of Business Ethics,11,3(2013).

4. Abdullah, Shamsul N., Ismail, Ku Nor Izah Ku and Nachum ,Lilac.Does Having Women on Boards Create Value? The Impact of Societal Perceptions and Corporate Governance in Emerging MarketsJ.Strategic Management

5. Yan Yonghai, Gender Diversification of Board of Directors and Corporate Financial Performance - Empirical Evidence Based on Small and Medium Board Listed Companies .J. Taiyuan: Friends of Accounting, 18(2014).

6. Cheng Rui, Ni Hengwang, Li Changqing .Study on the Risk Evasion of Women Directors and the Guaranty Behavior of the Board of Directors - Evidence from the Shanghai Stock Market .J. East China Economic Management(2016). 
7. Chang Mengmeng.CFO gender, financial stability and corporate finance decision-making relationship analysis .J. Business Economics Research(2015). 